\title{
Akıllı Telefon Kullanım Becerisi Bağlamında Okul Öncesi Öğretmenlerinin Nomofobi Eğilimlerinin İncelenmesi*
}

\author{
Deniz Mertkan Gezgin ${ }^{1}$, Nazire Burcin Hamutoglu ${ }^{2}$, Uğur Başarmak ${ }^{3}$, Ecem Seray Dă̆gl ${ }^{4}$
}

Özet: Mobil teknolojilerin kullanımının yaygınlaşması ile öğretmen ve öğrencilerin iletişimi ve bilgiye erişimi açısından büyük kolaylıklar sağlanmıştır ancak içinde bulunduğumuz çağın yeni olgusu olan ve bireyler için sosyal, psikolojik, zihinsel ve fiziksel bir tehdit oluşturan nomofobi hayatımızı olumsuz yönde etkilemeye başlamıştır. Bu çalışma ile okul öncesi öğretmenlerinin nomofobi düzeylerinin mesleki görev süresi, yaş ve akıllı telefon kullanım becerisi değişkenleri açısından incelenmesi amaçlanmıştır. Çalışma tarama modelinde betimsel bir çalışmadır. Çalışma grubunu Türkiye'nin farklı illerinde görev yapan 624 okul öncesi öğretmeni oluşturmaktadır. Analiz aşamasında mesleki görev süresi ve yaş değişkenlerinin kontrol edilmesi ile öğretmenlerin nomofobi düzeylerinin akıllı telefon kullanım becerisine göre anlamlı bir fark oluşturup oluşturmadığını belirlemek için ANCOVA testi uygulanmıştır. Analiz sonucunda elde edilen bulgular, uzman düzeyde akıllı telefon kullanım becerisine sahip okul öncesi öğretmenlerin nomofobi düzeylerinin, akıllı telefonlarını acemi ve orta düzeyde kullanan öğretmenlere göre yüksek düzeyde olduğunu ortaya koymaktadır. Elde edilen bulgular, akıllı telefon kullanım becerisinin artmasının nomofobi düzeyindeki artı̧ı da beraberinde getirebileceği riskini göstermektedir.

Anahtar kelimeler: Nomofobi, Teknoloji Becerisi, Okul Öncesi, Öğretmen, Yaş

Geliş Tarihi: 07.02.2020 - Kabul Tarihi: 17.05.2020 - Yayın Tarihi: 29.06.2020

DOI: $10.29329 / \mathrm{mjer} .2020 .258 .1$

\section{Investigation of Nomophobia Levels of Preschool Teachers in Terms of Different Variables}

Abstract: With the widespread use of mobile technologies, great convenience has been provided in terms of the communication of teachers and students and access to information, but nomophobia, which is a new phenomenon in the present era and which poses a social, psychological, mental and physical threat for

\footnotetext{
* Bu çalışmanın bir bölümü, 2017 yılı Nisan ayında Çanakkale'de düzenlenen Uluslararası Eğitimde Araştırmalar Kongresi 'nde (ULEAD) sözlü bildiri olarak sunulmuştur.

${ }^{1}$ Deniz Mertkan Gezgin, Assoc. Prof. Dr., Computer Education and Instructional Technology, Trakya University, ORCID: 0000-0003-4688-043X

${ }^{2}$ Nazire Burcin Hamutoglu, Instructor Dr., Computer Education and Instructional Technology, Eskisehir Technical University, ORCID: 0000-0003-0941-9070

Correspondence: bhamutoglu@sakarya.edu.tr

${ }^{3}$ Uğur Başarmak, Assist. Prof. Dr., Department of Computer and Instructional Technologies, Ahi Evran University, Faculty of Education, ORCID: 0000-0002-2762-1806

${ }^{4}$ Ecem Seray Dağlı, Pre-School Education, Trakya University Faculty of Education, ORCID: 0000-0002-5522-869X
} 
individuals, has started to affect our life negatively. This study, it is aimed to examine the nomophobia levels of preschool teachers in terms of the professional duty period, age and smartphone usage skill. The study is a descriptive study in the scanning model. In the study group, different provinces of Turkey that constitute task 624 pre-school teachers. ANCOVA test was applied in the analysis phase to determine whether the nomophobia levels of teachers make a significant difference according to the smartphone usage skill by controlling the duration of work and age variables. Findings obtained as a result of the analysis reveal that pre-school teachers who have expert level smartphone use skills have a higher level of nomophobia than teachers who use their smartphones at a novice and intermediate level. The findings show that the increase in the ability to use the smartphone may bring an increase in the level of nomophobia.

Keywords: Nomophobia, technology skill, pre-school, age, teacher.

\section{GíRiş}

Akıllı telefonlar sadece konuşmak ya da mesajlaşmak için değil aynı zamanda bilgisayar ortamından yapılabilecek birçok işi daha hızlı ve verimli bir şekilde gerçekleştirmek için kullanılırlar. Ancak akıl telefonların aşırı ve yoğun kullanımında bir bağımlılık haline dönüşebileceğinin bilinmesi gerekmektedir. Bir süre sonra bağımlılık düzeyindeki bu yoğun kullanım bireyler açısından olumsuz etkileri de ortaya çıaracaktır (Billieux, Maurage, Lopez-Fernandez, Kuss ve Griffiths, 2015; Nath, 2018; Pavithra, Madhukumar ve Mahadeva, 2015). Bu olumsuzlukların bireylerin telefonlarından uzak kaldıklarında endişe ve panik yaşamaları, iletişime geçemediklerinde kendilerini rahatsız hissetmeleri olarak ifade edilebilir. Günümüzde sanal dünyada daha çok zaman geçirdiğimiz için (Bhattacharya, Bashar, Srivastava ve Singh, 2019), mobil uygulamalar ile çok daha fazla süre harcama eğilimi ve kendini kontrol edememe davranışı belli bir süre sonra bireyde stres, kaygı, panik ve korku oluşturabilecek teknoloji rahatsızlıklarını ortaya çıkaracaktır (Gezgin, Hamutoğlu, Sezen-Gültekin ve Y1ldırım, 2019; Mallya, Kumar ve Mashal, 2018; Samaha ve Hawi, 2016; Tams, Legoux ve Léger, 2018).

Sosyal ağların yoğun kullanımı ile birlikte (Gezgin, Şahin ve Yıldırım, 2017) son zamanlarda ortaya çıkan Nomofobi (No Mobile Phone Phobia) kavramı, bireyler için sosyal, psikolojik, zihinsel ve fiziksel bir tehdit (Bhattacharya ve diğ., 2019; Singh, 2018; Tavolacci, Meyrignac, Richard, Dechelotte ve Ladner, 2015), davranışsal bağımlılık ve problemler yaratmaktadır (Bartwal ve Nath, 2019; De-Sola Gutiérrez, Rodríguez de Fonseca ve Rubio, 2016; Peraman ve Parasuraman, 2016). Günümüzün fobisi olarak nitelendirilen Nomofobi, akıllı telefondan yoksun olma korkusu (Ahmed, Pokhrel, Roy ve Samuel, 2019), akıllı telefon bağlantısından kopma korkusu (Bivin, Mathew, Thulasi ve Philip 2013; Bhattacharya ve diğ., 2019; González-Cabrera, León-Mejía, Pérez-Sancho ve Calvete, 2017; Yıldırım ve Kişioğlu, 2018), kişinin erişilemez olma korkusu (Adnan ve Gezgin, 2016; Argumosa-Villar, Boada-Grau ve Vigil-Colet, 2017; Dongre, Inamdar ve Gattani, 2017) gibi ifadelerle tanımlanmaktadır. Yıldırım ve Correia (2015)'a göre nomofobi’nin iletişim kuramamak, bağlantı 
kuramamak, bilgiye erişememek ve rahatlıktan vazgeçmek olmak üzere dört boyutu bulunmaktadır. Modern dünyanın fobisi (Adnan ve Gezgin, 2016) olarak kabul edilen nomofobi yeni teknolojilerin gelişiminin bir sonucu ve teknolojiyle temasta kalmamanın patolojik korkusu olduğu ifade edilmektedir (King, Valença ve Nardi, 2010). Bu bağımlılık durumu hem zaman hem de sosyal ve kültürel değişimin sonucu olarak görülmektedir (Carbonell, Chamarro, Oberst, Rodrigo ve Prades, 2018). Nomofobi ile ilgili alanyazında yapılan çalışmalar, nomofobi ile ilişkili bazı değişkenleri ortaya koymaktadır (Adnan ve Gezgin, 2016; Burucuoğlu, 2017; Büyükçolpan, 2019; Durak, 2018a; Durak, 2018b; Gezgin, Hamutoglu, Sezen-Gultekin ve Ayas, 2018; Gutiérrez-Puertas ve diğ., 2019; Güler ve Veysikarani, 2019; Mallya ve diğ., 2018; Sırakaya, 2018). Alanyazında nomofobi sorununu çözmeye ilişkin yapılan çalışmaların yeterli sayıda olmadığı ve nomofobiye yönelik çözüm önerilerinin geliştirilmesi gerektiği ifade edilmiştir (Ercan ve Tekin, 2019; Apak ve Yaman, 2019). Gerçekleştirilen bu çalışma ile okul öncesi öğretmenlerinin nomofobi düzeyleri üzerinde durulmuştur.

Okul öncesi eğitimi, çocuğun doğumundan ilkokula kadar olan çocukluk yıllarını içine almakta olup; çocukların gelişimlerinin toplumun kültürel değerleri hususunda, bireysel özellikleri ve gelişimsel düzeyleri dikkate alınarak, çocukların içinde bulundukları çevrenin uyarıcı zenginlikleri temelinde ele alınan bir eğitim süreci olarak tanımlanmaktadır (Oğuzkan ve Oral, 1983). Bu dönemin, çocuğun gelişimi için çok önemli olduğu söylenebilir. Buna göre, çocuğun gizil potansiyelini gerçekleştirmesinin ve gelecek yaşantısında olabilmesinin, içinde bulunduğu dönemi sağlıklı geçirmesine bağlı olduğunu söylemek mümkündür. Çalışmalar, çocukluk döneminde kazanılan davranışların daha sonraki yaşam dönemlerinde bireyin kişiliğini, inanç ve değer yargılarını önemli ölçüde biçimlendirdiğini ortaya koymaktadır (Emiroğlu, 2017; Kılıç ve Ayaz; 2018; Uzun ve Köse, 2017). Okul öncesi dönem çocuğun çevreye ve olgulara ilgisinin en yüksek olduğu dönemdir. $\mathrm{Bu}$ dönemde atılan temeller ileride çocuğun geleceğini oluşturacaktır. Bu yeniçağın yeni olgusu olan nomofobinin öğretmenler üzerinde incelenmesi özellikle okul öncesi bireylerin eğitimini veren öğretmenlerin mobil telefon kullanım davranışları ve nomofobi düzeylerinin önemli olduğu düşünülmektedir. $\mathrm{Bu}$ düşüncenin ardında, öğrencilere model olan ilk öğretmenlerin okul öncesi öğretmenleri olması, öğretmenlerin nomofobi yüzünden yaşadığı olumsuz etkilerle ders ve hayat konsantrasyonlarının kaybolmasının varlığı düşünülmektedir. Çalışma sonucunda elde edilen bulguların nomofobik eğilim gösteren okul öncesi öğretmenlerin nomofobi tarafindan karşılaşabilecekleri olumsuz etkilerin azaltılması ve bu konuda farkındalık sağlaması açısından katkılar sağlayacağı düşünülmektedir. Böylelikle hem okul öncesi öğretmenleri ve hem de eğitim verdikleri öğrenciler açısından daha sağlıklı bir ders ortamı, eğitim ortamı ve ilerisi için daha bilinçli teknoloji kullanan bireylerin yetişmesi sağlanabilir. Temel hipotez olarak akıllı telefonlarını çeşitli amaçlar için kullanmayı beceren yaşı ne olursa olsun her bireyin nomofobi riski taşıması olasılığıdır. $\mathrm{Bu}$ doğrultuda, çalışmada okul öncesi öğretmenlerinin görev süresinin yaş ile birlikte artması beklendiğinden, görev süresi ve yaş değişkeni kontrol altına alınmış, bu değişkenlerin etkisinden 
bağımsız olarak oluşan okul öncesi öğretmenlerinin akıllı telefon kullanım becerilerine (ATKB) göre ayrılmış gruplar arasında nomofobi düzeyi açısından anlamlı bir farkın olup olmadığının incelenmesi amaçlanmıştır. Böylelikle ATKB düzeyi ile nomofobi arasındaki olası ilişkinin ortaya konulması söz konusudur.

$\mathrm{Bu}$ amaç doğrultusunda çalışmada aşağıdaki sorulara yanıt aranmıştır:

1. Okul öncesi öğretmenlerinin nomofobi düzeyleri ile yaş, görev süresi değişkenleri arasındaki ilişki nasıldır?

2. Okul Öncesi Öğretmenlerine ait görev süresi değişkeni kontrol edildiğinde, öğretmenlerin nomofobi ölçeğinden aldıkları puanlar akıllı telefon kullanım beceri düzeylerine göre anlamlı bir farkl111k göstermekte midir?

3. Okul Öncesi Öğretmenlerine ait yaş değişkeni kontrol edildiğinde, öğretmenlerin nomofobi ölçeğinden aldıkları puanlar akıllı telefon kullanım beceri düzeylerine göre anlamlı bir farklılık göstermekte midir?

\section{YÖNTEM}

\section{Araştırma Modeli}

$\mathrm{Bu}$ çalışma, betimsel tarama yöntemine uygun olarak desenlenmiş olup; var olan bir durumu betimlemeyi amaçlamaktadır. $\mathrm{Bu}$ amaçla, araştırma konusu ile ilgili mevcut durumun fotoğrafının çekilerek tanımlanması söz konusudur (Büyüköztürk, Akgün, Demirel, Karadeniz ve Çakmak, 2015). Fraenkel ve Wallen (2006) betimsel tarama yöntemiyle desenlenen çalışmaların araştırmada ele alınan değişkenlerin konu ile ilgili olan durumunu değiştirme ve etkileme çabası olmadan, görüşlerin ve özelliklerin nedenlerinden ziyade, çalışmadaki katılımcıların nasıl dağılım gösterdiği ortaya koyduğunu ifade etmektedir.

\section{Çalışma Grubu}

Çalışma grubunu Türkiye'nin farklı illerinde görev yapan 624 okul öncesi öğretmeni oluşturmaktadır. Okul öncesi öğretmenlerin 581'i $(\% 93,1)$ kadın, 43’ü $(\% 6,9)$ erkektir. Katılımcıların yaş ortalaması $\bar{X}=28,36$ ve görev süresi ortalaması $\bar{X}=5.67$ olarak tespit edilmiştir.

\section{Veri Toplama Aracı}

Araştırma verileri; araştırmacılar tarafından hazırlanan bir bilgi formu ve Yildirim ve Correia (2015) tarafından geliştirilen ve Yildirim, Sumuer, Adnan ve Yildirim (2016) tarafından Türkçeye uyarlanan Nomofobi Ölçeği (NMP-Q) ölçeği kullanarak toplanmıştır. Demografik verileri elde etmek amacıyla hazırlanan bilgi cinsiyet, yaş, görev süresi ve akıllı telefon kullanım becerisini (Acemi, Orta, Uzman) ölçmeye yönelik sorulardan oluşmaktadır. Akıllı telefon kullanım becerisini düzeylerine belirli görevler atanarak, bu görevlere göre öğretmenlerin düzeylerini seçmesi sağlanmıştır. 
Nomofobi ölçeği 7'li Likert tipinde, toplam 20 maddeden oluşmaktadır. Geliştirilen ölçeğin Cronbach Alpha ile hesaplanan iç tutarlık katsayısı .95'tir. Uyarlama çalışmaları sonucunda da Cronbach Alpha ile elde edilen iç tutarlık katsayısı ise .92 olarak raporlanmıştır. Ölçeğin Bilgiye Erişememe (4 madde), Bağlantıyı Kaybetme (5 madde), İletişime Geçememe (6 madde) ve Rahat Hissedememe (5 madde) olmak üzere dört alt boyutu bulunmaktadır. Geliştirilen ölçeğin mevcut alt boyutlarında hesaplanan güvenirlik katsayıları sırasıyla. $94, .87, .83$ ve .81 olarak bulunmuştur. Türk Nomofobi Ölçeği (NMP-Q)'nun geçerliliği ve güvenilirliği için gerçekleştirilen ön testte NMP-Q'nun güvenilirliğinin tatmin edici derecede yüksek olduğu bulunmuştur (Cronbach'ın alfa $=.92$ ). Dahas1, Cronbach'ın dört alt boyutun alfa değerleri sirasılyla 90, 0,74, .94 ve .91'dir ve bu da tatmin edici derecede yüksek güvenilirliği gösterdiği ifade edilmiştir. Sonuç olarak, Türk NMP-Q, nomofobinin geçerli ve güvenilir bir ölçüsü olduğu şeklinde raporlanmıştır.

\section{Verilerin Toplanması ve Analizi}

Araştırmada veri toplama süreci, araştırmacılar tarafından çevrimiçi Google anket formu vasıtasıyla okul öncesi öğretmenlerinin üye oldukları forum sayfasından 1 ay süreyle gönüllülük esasına göre toplanmıştır. Araştırmada gerçekleştirilen analizler SPSS (The Statistical Package for the Social Sciences) programı kullanılarak yapılmıştır. Araştırmanın problemlerine yanıt bulmak amacıyla standart sapma, ortalama, korelasyon, tek yönlü varyans analizi (ANCOVA) gibi analizlerden faydalanılmıştır. Mesleki görev süresi ve yaş değişkenleri kontrol edildiğinde, öğretmenlerin nomofobi ölçeğinden aldıkları puanlar mobil kullanım düzeylerine göre anlamlı bir fark oluşturup oluşturmadığını belirlemek için ANCOVA yapılmıştır. Normal dağılım için basıklık-çarpıklık değerlerinden faydalanılmıştır ( \pm 1.96.) (Tabachnick, Fidell ve Ullman, 2007). Elde edilen veri setinin basıklık-çarpıklık problemlerinin olmadığı ve normallik varsayımını sağladığı tespit edilmiştir. Ayrıca Levene testinden faydalanılarak grupların varyans homojenliği kontrol edilmiştir ( $p>0.05)$. Son olarak, elde edilen farklılığın hangi mobil kullanım düzeyine sahip gruplar arasında olduğunu belirlemek için ise Bonferroni testinden faydalanılmıştır. Yapılan hesaplamalarda istatistiksel anlamlılık düzeyi 0.05 olarak alınmıştır.

\section{BULGULAR}

Araştırma sorusu olarak ifade edilen "Okul öncesi öğretmenlerinin nomofobi düzeyleri ile yaş, görev süresi değişkenleri arasındaki ilişki nasıldır?” sorusuna yönelik elde edilen bulgular Tablo 1'de gösterilmektedir. 
Tablo 1. Yaş, Görev Süresi ve Nomofobi Değişkenlerine Göre Betimsel İstatistikler ve Korelasyon Değerleri

\begin{tabular}{lllllll}
\hline & $\bar{X}$ & $\mathrm{Sd}$ & $\mathrm{N}$ & Yaş & Görev süresi & Nomofobi \\
\hline Yaş & 28.36 & 6.07 & 624 & 1 & & \\
Görev süresi & 5.67 & 5.34 & 624 & $0.831^{* *}$ & 1 & \\
Nomofobi & 3.67 & 1.44 & 624 & $-0.103^{*}$ & $-0.101^{*}$ & 1 \\
\hline$* * \mathrm{p}<0.01, * \mathrm{p}<0.05$ & & & & & &
\end{tabular}

Tablo 1 incelendiğinde katılımcıların yaş, görev süresi ve nomofobi değişkenleri arasındaki korelasyonu açısından yaş ile görev süresi arasında yüksek düzeyde anlamlı ve pozitif bir ilişkinin olduğu görülmektedir ( $\mathrm{r}_{\text {yaş }}$-görev süresi $=0.831, \mathrm{p}<0.01$ ). Ayrıca elde edilen bulgular nomofobi ile yaş ve görev süresi değişkenleri arasında düşük düzeyde anlamlı ve negatif bir ilişkinin varlığını

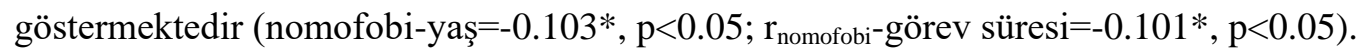

Araştırma sorusu olarak ifade edilen "Okul öncesi öğretmenlerinin nomofobi düzeyleri ile yaş, görev süresi değişkenleri arasındaki ilişki nasıldır?” sorusuna yönelik elde edilen bulgular Tablo 2, 3 ve 4'de gösterilmektedir. Öğretmenlerin görev sürelerine göre düzeltilmiş nomofobi ölçeğinden aldıkları puanlar ise Tablo 2'de gösterilmektedir.

Tablo 2. Nomofobi Ölçeği Puanlarının ATKB Düzeyine Göre Betimsel İstatistikler

\begin{tabular}{llll}
\hline Mobil Kullanım Düzeyi & $\mathrm{N}$ & $\bar{X}$ & Düzeltilmiş $\bar{X}$ \\
\hline Acemi & 248 & 3.36 & 3.37 \\
Orta & 282 & 3.70 & 3.70 \\
Uzman & 94 & 4.43 & 4.40 \\
\hline
\end{tabular}

Düzeltilmiş nomofobi ölçeği ortalama puanlarına göre ATKB düzeyleri incelendiğinde, en yüksek nomofobi puanına uzmanlık derecesinde ATKB düzeyine sahip öğretmenlerin olduğu, bunu sırasıyla orta ve acemi derecesinde ATKB düzeyindeki öğretmenlerin izlediği ifade edilebilir. Grupların düzeltilmiş nomofobi ölçeği ortalama puanları arasında gözlenen farkın anlamlı olup olmadığını test etmek amacıyla verilere ANCOVA analizi yapılmıştır.

Tablo 3. Görev Süresi Değişkenine Göre Düzeltilmiş Nomofobi Ölçeği Puanlarının ATKB Düzeyine Göre ANCOVA Sonuçları

\begin{tabular}{lllllll}
\hline Varyansın Kaynağ & K.T & Sd & KO & F & P & Eta-kare \\
\hline Görev Süresi & 4.020 & 1 & 4.020 & 2.069 & 0.151 & 0.003 \\
Mobil Kullanım Düzeyi & 69.798 & 2 & 34.899 & 17.961 & 0.000 & 0.055 \\
Hata & 1204.697 & 620 & 1.943 & & & \\
Toplam & 9714.682 & 624 & & & & \\
\hline
\end{tabular}


Tablo 3'te verilen ANCOVA sonuçlarına göre, farklı ATKB düzeylerine sahip öğretmenlerin mesleki görev süresi değişkenine göre düzeltilmiş nomofobi ölçeği ortalama puanları arasında anlamlı bir farkın olduğu bulunmuştur. Öğretmenlerin nomofobi puanları $[F(2,620)=17.961 p<0,05]$. Başka bir deyişle, öğretmenlerin nomofobik davranışları ATKB düzeyleri ile ilişkilidir. Eta-kare değerleri incelendiğinde ise, ATKB düzeyi, görev süresi değişkeninden bağımsız olarak, nomofobi ölçeği puanlarındaki değişkenliğin \%5,5'ini açıkladığı görülmektedir. Buna bağlı olarak farklı ATKB düzeylerine sahip grupların görev süresi değişkenine göre düzeltilmiş nomofobi ölçeği puanları arasında yapılan Tablo 4'teki Bonferroni testi sonuçlarına göre ATKB düzeyi uzman olan öğretmenlerin nomofobi puanları $(\bar{X}=4,40)$ orta $(\bar{X}=3,70)$ ve acemi $(\bar{X}=3,37)$ kullanım düzeyine sahip öğretmenlerden daha fazladır. Ayrıca orta düzey ATKB sahip öğretmenlerin $(\bar{X}=3,70)$, acemi ATKB düzeyine sahip öğretmenlerden $(\bar{X}=3,37)$ daha yüksek nomofobi puanına sahip olduğu da elde edilen bulgular arasindadir.

Tablo 4. Görev Süresi Değişkenine Göre Düzeltilmiş Nomofobi Ölçeği Puanları Arasındaki Bonferroni Testi Sonuçları

\begin{tabular}{llll}
\hline ATKB & Ortalama Fark1 & SE & $\mathrm{p}$ \\
\hline Orta-Acemi & 0.325 & 0.122 & 0.024 \\
Uzman-Acemi & 1.028 & 0.172 & 0.000 \\
Uzman-Orta & 0.703 & 0.167 & 0.000 \\
\hline
\end{tabular}

Araştırmanın problemi olarak ifade edilen "Yaş değişkeni kontrol edildiğinde, öğretmenlerin nomofobi ölçeğinden aldıkları puanlar akıllı telefon kullanım becerisi düzeylerine göre anlamlı bir farklılık göstermekte midir? Sorusuna yönelik elde edilen bulgular aşağıda yer almaktadır:

Buna göre öğretmenlerin yaş değişkenine göre düzeltilmiş nomofobi ölçeğinden aldıkları puanlar Tablo 5'te gösterilmektedir.

Tablo 5. Yaş Değişkenine Göre Düzeltilmiş Nomofobi Ölçeği Puanlarının ATKB Göre ANCOVA Sonuçları

\begin{tabular}{lllllll}
\hline Varyansın Kaynağı & K.T & Sd & KO & F & p & Eta-kare \\
\hline Yaş & 4.000 & 1 & 4.000 & 2.059 & 0.152 & 0.003 \\
Mobil Kullanım Düzeyi & 69.245 & 2 & 34.623 & 17.818 & 0.000 & 0.054 \\
Hata & 1204.717 & 620 & 1.943 & & & \\
Toplam & 9714.683 & 624 & & & & \\
\hline
\end{tabular}

Tablo 5'te verilen ANCOVA sonuçlarına göre, farklı ATKB düzeylerine sahip öğretmenlerin yaş değişkenine göre düzeltilmiş nomofobi ölçeği ortalama puanları arasında anlamlı bir farkın olduğu 
bulunmuştur $[\mathrm{F}(2,620)=17.818 \mathrm{p}<0,05]$. Başka bir deyişle, öğretmenlerin nomofobik davranışları ATKB düzeyleri ile ilişkilidir. Eta-kare değerleri incelendiğinde ise, ATKB düzeyi, yaş değişkeninden bağımsız olarak, nomofobi ölçeği puanlarındaki değişkenliğin \%5,4'ünü açıkladığı görülmektedir. Buna bağlı olarak farklı ATKB düzeylerine sahip grupların yaş değişkenine düzeltilmiş nomofobi ölçeği puanları arasında yapılan Bonferroni testi sonuçları Tablo 6' da gösterilmektedir.

Tablo 6. Yaş Değişkenine Göre Düzeltilmiş Nomofobi Ölçeği Puanları Arasındaki Bonferroni Testi Sonuçları

\begin{tabular}{llll}
\hline Mobil Kullanım Düzeyi & Ortalama Farkı & SE & P \\
\hline Orta-Acemi & 0.317 & 0.123 & 0.030 \\
Uzman-Acemi & 1.026 & 0.172 & 0.000 \\
Uzman-Orta & 0.709 & 0.167 & 0.000 \\
\hline
\end{tabular}

Tablo 6'da verilen Analiz sonuçlarına göre ATKB düzeyi uzman olan öğretmenlerin nomofobi puanları $(\bar{X}=4.40)$, orta $(\bar{X}=3.70)$ ve acemi $(\bar{X}=3.37)$ ATKB düzeyine sahip öğretmenlerden daha fazla olduğu tespit edilmiştir. Ayrıca orta düzey ATKB sahip öğretmenlerin $(\bar{X}=3.70)$, acemi ATKB düzeyine sahip öğretmenlerden $(\bar{X}=3.37)$ daha yüksek nomofobi puanına sahip olduğu da elde edilen bulgular arasindadır.

\section{SONUÇ, TARTIŞMA VE ÖNERILER}

Okul öncesi öğretmenlerinin nomofobi düzeylerinin ATKB, yaş ve görev süresine göre incelendiği bu çalışmanın bulguları sonucunda uzman olarak akıllı telefonunun kullanan okul öncesi öğretmenlerinin aynı şekilde nomofobi düzeylerinin akıllı telefonunu acemi, orta düzeyde kullanan öğretmenlere göre yüksek olduğu ortaya çıkmıştır. Uzman bir şekilde akıllı telefon kullanan bireylerin nomofobi düzeyinin yüksek çıkması, nomofobi ile yapılan alanyazındaki çalışmalarda tespit edilen yoğun akıllı telefon kullanan bireylerin nomofobi düzeyinin yüksek çıkmasına referans gösterilebilir (Adnan ve Gezgin, 2016; Hoşgör, Tandoğan ve Hoşgör Gündüz, 2017). Çünkü yoğun bir şekilde akı1lı telefon kullanan bireylerin akıllı telefonlarını kullanım açısından uzmanlaşması ve akıllı telefonların güncellemelerine açık olması doğal bir süreç olarak düşünülmektedir. Çalışmada ATKB için akıllı telefonu açıp-kapatabilme, ekran ve tuş kontrollerini yapabilme, mobil uygulamalar yükleme/kaldırma, sosyal medya hesaplarını kontrol edebilme, rahat bir şekilde tüm iletişim kanallarından iletişime geçebilme, saat ve alarm kurabilme, aradığını rahatlıkla bulabilme ve dosya yönetimi özellikleri ele alınmıştır. Bu özelliklere sahiplik düzeyi artan bir birey telefonunu daha rahat, kolay ve çeşitli şekillerde kullanabilmektedir. Sosyal ağ sitelerinde kurulan sanal ortamın ve iletişimin, hayatın rutin işlerinin akıllı telefon üzerinden yapılmasının, sabah işe geç kalmamak için bile akıllı telefonun saatinin kullanılmasının ve ayrıca gelişen teknoloji ve değişen ihtiyaçlar açısından akıllı telefonların uzman bir şekilde kullanılmasının özellikle akıllı telefonları hayatın bir parçası haline 
getirmektedir (Bayram, Yılmaz, Sözen ve Bayer, 2019). Bu bulgu sonucunda, ATKB düzeyi düşük olan bireylerin nomofobi düzeyinin düşük olduğu genellemesi yapılamasa bile ATKB düzeyi arttıkça mobil teknolojilere olan yakınlığın artmış olduğu ve bunun sonucu olarak hayatının bir parçası haline gelen özellikle akıllı telefonlar yüzünden okul öncesi öğretmenlerinin nomofobi riski taşıdıklarını söyleyebiliriz. Fakat nomofobinin temelinde arkadaşlara ve ebeveynlere ulaşamadığında yaşanan korku durumu da mevcut olduğundan, nomofobinin akıllı telefon kullanım yoğunluğu ve becerisinin yanında bireyin kişisel özellikleri, kaygı, duygu-durum değişikliği ve özellikle yalnızlık (Jiang ve Shypenka, 2018; Jin ve Park, 2012; Ozdemir, Cakir ve Hussain, 2018; Reid ve Reid, 2007; Tan, Pamuk ve Dönder, 2013; Wei ve Lo, 2006; Gezgin ve diğ., 2018) gibi durumlardan da nemalandığ1 düşünülmektedir. Çünkü kaygı bozukluğu taşıyan ya da panik atak derecesinde rahatsızlığı olan bireylerin akı1lı telefonları yerine geleneksel bir tipte cep telefonlarına sahip olsalar bile aile fertlerine, arkadaşlarına ulaşamadıklarında ve telefon yanlarında olmadığında nomofobik davranış gösterebilmektedir. Sonuç olarak, bu psikolojik etmenler yüzünden bireyin yoğun akıllı telefon ve mobil sosyal medya kullanımı nomofobik davranışların ortaya çıkmasında rol almaktadır (Gezgin ve diğ., 2017; Gezgin ve diğ., 2018; Y1ldız Durak, 2018).

Çalışmanın diğer bulgusu olarak okul öncesi öğretmenlerin nomofobi düzeyleri ile görev süreleri, yaş değişkenleri arasında negatif anlamlı bir ilişkinin olduğu görülmektedir. Nomofobi ile yapılan alanyazın taramasında genellikle çalışmaların üniversite öğrencileri ve ergenler üzerinde olduğu görülmüsstür (Adnan ve Gezgin,2016). Fakat bu çalışmalardaki katılımcıların yaş aralığında için bile düşünülse, katılımcıların yaş düzeylerinin düşmesi sonucu nomofobinin arttığ1 gözlemlenmiştir (Gezgin, Şumuer, Arslan ve Yıldırım, 2017; SecurEnvoy, 2012). Bu bulguyu, dijital yerli (Prensky, 2001) olarak adlandırılan ergenlerin ve üniversite öğrencilerinin teknoloji adaptasyonlarının yüksek olması ve yetişme evresinde akıllı telefonların bu kuşakların hayatının içerisinde daha fazla yer kaplaması nedeniyle alışkanlıkların değişmesine bağlayabiliriz (Bayram ve diğ., 2019).

Son olarak, yaş ve görev süresi kontrol edildiğinde okul öncesi öğretmenleri arasında ATKB düzeyine göre ayrılmış gruplar içerisinde anlamlı farkın nomofobi düzeyi yüksek grup lehine olduğu görülmüştür. $\mathrm{Bu}$ doğrultuda, her yaş ve kariyer evresinde bir bireyin ATKB düzeyi yükselmeye başladığında yani uzmanlaşmaya doğru gidildiğinde birey nomofobi riski taşımaktadır diyebiliriz. Bir başka deyişle, yaşı ve kariyeri ne olursa olsun teknoloji yeterliliği ve yatkınlığı olan gelişmelere açık, kendini güncelleyen öğretmenlerin nomofobi riski taşıdıkları söylenebilir. Bu durumu, Griffiths'in (2003) öneri olarak ifade ettiği haz veren her şeyin bağımlılık yaptığı ifadesi ile açıklayabiliriz. Çünkü akıllı telefonun ihtiva ettiği binlerce mobil uygulama ile bireye haz vermesi, bireyin akıllı telefona bağımlı hale gelmesini sağlayabilmektedir. Akıllı telefona bağımlı hale gelindiğinde bireyin nomofobik davranış göstermesi kaçınılmaz bir hale gelmektedir. Toplumda $Z$ ve $Y$ kuşağının akıllı telefonla ilişkisinin yoğunluğu yüzünden öne çıkması açısından (Choudhary, 2014) bu grup için 
nomofobinin daha yüksek risk teşkil ettiği söylenebilir. Çünkü bu kuşaktaki bireyler için eğlence, iletişim, eğitim amaçlı kullanımı olan akıllı telefonlar bir ihtiyaçtan çok bir statü göstergesi ve kimliğini oluşturma ve destekleme aracı olarak kullanılabilmektedir (Kuyucu, 2017). Fakat çalışmada, $\mathrm{X}$ kuşağ 1 ya da dijital göçmen diye nitelendirilen yaş grubu bireyler için de uzman bir şekilde akıllı telefonunu kullanan okul öncesi öğretmenlerinin nomofobi düzeyinin yüksek çıkması, bu bireylerin kariyer evrelerinin sonunda olması yüzünden bir tükenmişlik (Bayram ve diğ., 2019) ve aidiyet duygusunun düşüklüğü (Aşık, 2018) açısından yorumlanabilir. Bu sendromların bireyi farklı arayışlara yönlendirebileceği ve hayattan alabileceği heyecanı; akıllı telefon, mobil oyunlar ve mobil sosyal ağ uygulamaları kullanarak elde edebilmesinin birey için nomofobi riski teşkil ettiği söylenebilir. Bunu destekler şekilde davranışçı yaklaşım açısından konu ele alınabilir. Cüceloğlu (1993)'ün ifade ettiği gibi davranış̧̧ı yaklaşıma göre, eğer bir davranış gerginlik ve sıkıntı gibi olumsuz bir davranıştan kurtulmaya olumlu bir şekilde yardımcı oluyorsa, o davranış tekrarlanmakta ve birey daha sonra karşılaştı̆̆ 1 aynı olumsuz his ve durumda haz almak ya da olumsuzluktan kurtulmak için o davranışı yapmayı seçmektedir.

Çalışma sonucunda, ATKB düzeyinin artmasının her yaşta ve kariyer evresinde nomofobi riskini arttırdığı sonucuna varabiliriz. X kuşağı daha geleneksel olarak kabul edilse de bu kuşakta da teknoloji yeterliliği olan ve teknolojik gelişmelere açık olan yaşı nispeten büyük okul öncesi öğretmenlerinin uzman olarak kullandıkları akıllı telefon kullanımı yüzünden nomofobiden etkilenebilecekleri görülmektedir. Okul öncesi öğretmenlerinin akıllı telefonlarını uzman olarak kullanmaları bilgiye ulaşabilme, meslektaşları ile iletişime geçme ve öğrenme-öğretmeyi desteklemek açısından onlara fayda sağlamaktadır (Bozkurt, 2015). Fakat bilinçli mobil teknoloji kullanım kavramı göz ardı edilirse okul öncesi öğretmenleri çoğu işlerini kolaylıkla ve uzmanlıkla yaptığı akıllı telefonlarına bağımlı hale gelebilmektedir. Bu açıdan bilinçli, kontrollü ve çeşitli amaçlarla akıllı telefon kullanımının önemi her yaşta ve meslekte ortaya çıkmaktadır. Çünkü bilinçsiz ve kontrolsüz bir şekilde kullanılan akıllı telefonlar öğrenme, hafiza ve hatırlama (Tanil ve Yong, 2019), odaklanma (Nath, 2018) üzerinde olumsuz etkiler göstermektedir. Bu olumsuz durumlar öğrencilerin ilk öğretmeni, rol modeli olan okul öncesi öğretmenleri açısından sadece kendileri için değil öğrencilerin eğitimi ve öğretimi açısından da aksaklıkların doğmasına yol açabilecektir. Çalışmada elde edilen bulgulara dayalı olarak akıllı telefonların ihtiyaç nezdinde kullanılması gerektiği fikri her geçen gün ağır basmakta olup, boş zaman aktivitesi olarak kullanmaktan öteye gidilmesi gerekliliği önem kazanmaktadır. İleri de yapılacak çalışmalarda, mobil kullanım düzeyi için farklı ölçme yöntemleri kullanılabilir. Böylelikle, kişinin boş zamanlarında akıllı telefonunda yüklü uygulamalar ile etkileşime girerek deneyim kazanmasının ATKB düzeyinde meydana getireceği bilinçsiz ve kontrolsüz artışın önüne geçilmesi ile nomofobi riskinin de azalabileceği düşünülmektedir. Bu açıdan bireylerin dijital okuryazarlık becerilerinin arttırılması yönünde gerçekleştirilecek çalışmaların da nomofobi ile mücadele açısından etkili sonuçları olabileceği söylenebilir. Ayrıca çalışmada elde edilen bulgular 
doğrultusunda okul öncesi öğretmenlerinin bağlı oldukları okullarda ders sırasında akıllı telefon kullanımı hususunda doğru strateji ve politikalar oluşturulmasının uygun olacağı ortaya çıkmaktadır. Son olarak, kariyer evrelerine göre yeni işe başlayan öğretmenlerin yada daha uzun yıllar mesleği yürüten öğretmenlerin aidiyet, tükenmişlik durumları ile nomofobi ilişkisinin incelenmesi alanyazın için yararlı olacaktır (Bayram ve di ̌̆., 2019).

\section{KAYNAKLAR}

Adnan, M. ve Gezgin, D. M. (2016). A Modern Phobia: Prevalence of Nomophobia among College Students 1. Ë̆itim Bilimleri Fakültesi Dergisi, 49(1), 141-158.

Ahmed, S., Pokhrel, N., Roy, S., \& Samuel, A. J. (2019). Impact of nomophobia: a nondrug addiction among students of physiotherapy course using an online cross-sectional survey. Indian Journal of Psychiatry, 61(1), 77.

Apak, E. ve Yaman, Ö. M. (2019). Üniversite öğrencilerinde nomofobi yaygınlığı ve nomofobi ile sosyal fobi arasındaki ilişki: Bingöl Üniversitesi örneklemi. Addicta: The Turkish Journal on Addictions, 6, 609-627. http://dx.doi.org/10.15805/addicta.2019.6.3.0078

Argumosa-Villar, L., Boada-Grau, J., \& Vigil-Colet, A. (2017). Exploratory investigation of theoretical predictors of nomophobia using the mobile phone involvement questionnaire (MPIQ). Journal of Adolescence, 56, 127-135.

Aşık, N. A. (2018). Aidiyet duygusu ve nomofobi ilişkisi: turizm öğrencileri üzerinde bir araştırma. Turar Turizm \& Araştırma Dergisi, 7(2), 24-42.

Bartwal, J., \& Nath, B. (2019). Evaluation of nomophobia among medical students using smartphone in north India. Medical Journal Armed Forces India. (In press). https://doi.org/10.1016/j.mjafi.2019.03.001

Bayram, A., Yılmaz, E. Z., Sözen, Ç. ve Bayer, N. (2019). nomofobi'nin (akıllı telefon yoksunluğu) içsel motivasyona etkisi: Giresun üniversitesi öğrencileri örneği. İşletme Bilimi Dergisi, 7(1), 105-130.

Bhattacharya, S., Bashar, M. A., Srivastava, A., \& Singh, A. (2019). NOMOPHOBIA: NO MObile PHone PhoBIA. Journal of family medicine and primary care, 8(4), 1297.

Billieux, J., Maurage, P., Lopez-Fernandez, O., Kuss, D. J., \& Griffiths, M. D. (2015). Can disordered mobile phone use be considered a behavioral addiction? An update on current evidence and a comprehensive model for future research. Current Addiction Reports, 2(2), 156-162.

Bivin, J. B., Mathew, P., Thulasi, P. C., \& Philip, J. (2013). Nomophobia-do we really need to worry about. Reviews of Progress, 1(1).1-5.

Bozkurt, A. (2015). Mobil Öğrenme: Her zaman, her yerde kesintisiz öğrenme deneyimi. Açıöğretim Uygulamaları ve Araştırmaları Dergisi, 1(2), 65-81.

Burucuoğlu, M. (2017). Meslek yüksekokulu öğrencilerinin nomofobi düzeyleri üzerinde bir araştırma. Karabük Üniversitesi Sosyal Bilimler Enstitüsü Dergisi, 7(2), 482-489.

Büyükçolpan, H. (2019). Üniversite öğrencilerinde nomofobi, bağlanma biçimleri, depresyon ve algılanan sosyal destek. (Yayımlanmış yüksek lisans tezi) Hacettepe Üniversitesi, Eğitim Bilimleri Enstitüsü, Ankara. 
Büyüköztürk, Ş., Akgün, Ö. E., Demirel, F., Karadeniz, Ş. ve Çakmak, E. K. (2015). Bilimsel araştırma yöntemleri. Pegem Akademi.

Carbonell, X., Chamarro, A., Oberst, U., Rodrigo, B., \& Prades, M. (2018). Problematic use of the internet and smartphones in university students: 2006-2017. International Journal Of Environmental Research And Public Health, 15(3), 1-13.

Choudhary, A. (2014). Smartphones and their impact on net income per employee for selected u.s. Firms, Review of Business And Finance Studies, 5(2).

Cüceloğlu, D. (1993). Insan ve Davranışı. İstanbul: Remzi Kitapevi Yayınları

De-Sola Gutiérrez, J., Rodríguez de Fonseca, F., \& Rubio, G. (2016). Cell-phone addiction: a review. Frontiers in psychiatry, 7, 175.

Dongre, A. S., Inamdar, I. F., \& Gattani, P. L. (2017). Nomophobia: a study to evaluate mobile phone dependence and impact of cell phone on health. National Journal of Community Medicine, , 8(11), 688-93.

Durak, H. Y. (2018a). Investigation of nomophobia and smartphone addiction predictors among adolescents in Turkey: Demographic variables and academic performance. The Social Science Journal.(In press). https://doi.org/10.1016/j.soscij.2018.09.003.

Durak, H.Y. (2018b). What would you do without your smartphone? Adolescents' social media usage, locus of control, and loneliness as a predictor of nomophobia. Addicta: The Turkish Journal On Addictions.

Emiroğlu, B. (2017). Değerler eğitiminin gençlerin sağlıklı sosyalleşmelerine etkisi. International Journal Of Eurasian Education And Culture, 2(3), 115-126.

Ercan, Ö. ve Tekin, N. (2019). Beden eğitimi öğretmenlerinin nomofobi düzeylerinin incelenmesi. Journal of Global Sport and Education Research, 2(1), 24-34.

Fraenkel R. J., \& Wallen E. N. (2006). How to Design and Evaluate Research in Education. McGraw-Hill, New York.

Gezgin, D. M., Şumuer, E., Arslan, O. ve Yıldırım, S. (2017). Nomophobia prevalence among pre-service teachers: a case of Trakya university. Trakya Üniversitesi Eğitim Fakültesi Dergisi, 7(1), 86-95.

Gezgin, D. M., Şahin, Y. L. ve Yıldırım, S. (2017). Sosyal ağ kullanıcıları arasında nomofobi yaygınlığının çeşitli faktörler açısından incelenmesi. Eğitim Teknolojisi Kuram Ve Uygulama, 7(1), 1-15.

Gezgin, D. M., Hamutoglu, N. B., Sezen-Gultekin, G. ve Ayas, T. (2018). The relationship between nomophobia and loneliness among Turkish adolescents. International Journal of Research in Education and Science, 4(2), 358-374.

Gezgin, D. M., Hamutoğlu, N. B., Sezen-Gültekin, G. ve Yıldırım, S. (2019). Preservice teachers' metaphorical perceptions on smartphone, no mobile phone phobia (nomophobia) and fear of missing out (FoMO). Bartın University Journal of Faculty of Education, 8(2), 733-783

González-Cabrera, J., León-Mejía, A., Pérez-Sancho, C., \& Calvete, E. (2017). Adaptation of the Nomophobia Questionnaire (NMP-Q) to Spanish in a Sample of Adolescents. Actas Esp Psiquiatr, 45(4), 137-44.

Griffiths, M. D. (2003). Internet gambling: issues, concerns and recommendations. Journal of Cyberpsychology \& Behavior, 6(6), 557-568. 
Güler, E. Ö. ve Veysikarani, D.(2019). Nomofobi üzerine bir araştırma: üniversite öğrencileri örneği. Beykoz Akademi Dergisi, 7(1), 75-88.

Hoşgör H., Tandoğan Ö. ve Hoşgör Gündüz D. (2017). Nomofobinin günlük akıllı telefon kullanım süresi ve okul başarısı üzerindeki etkisi: sağlık personeli adayları örneği. The Journal of Academic Social Science, 5(46),573-595

Jiang, Q., Li, Y., \& Shypenka, V. (2018). Loneliness, individualism, and smartphone addiction among international students in China. Cyberpsychology, Behavior, And Social Networking, 21(11), 711718.

Jin, B., \& Park, N. (2012). Mobile voice communication and loneliness: cell phone use and the social skills deficit hypothesis. New Media \& Society. 15(7), 1094-1111.

Kılıç, Ö. Ö. ve Ayaz, C. Ö. (2018). 5-6 yaş grubu çocukların değerlere yönelik farkındalık düzeyini arttırmada değerler eğitimi programının etkisi. Journal Of International Social Research, 11(59).

King, A. L. S., Valença, A. M., \& Nardi, A. E. (2010). Nomophobia: The mobile phone in panic disorder with agoraphobia: reducing phobias or worsening of dependence?. Cognitive And Behavioral Neurology, 23(1), 52-54.

Kuyucu, M. (2017). Gençlerde akıllı telefon kullanımı ve akıllı telefon bağımlılığı sorunsalı:"akı1llı telefon (kolik)" üniversite gençliği. Global Media Journal TR Edition, 7(14), 328-359.

Mallya, N. V., Kumar, S. D., \& Mashal, S. (2018). A study to evaluate the behavioral dimensions of" nomophobia" and attitude toward smartphone usage among medical students in Bengaluru. National Journal of Physiology, Pharmacy and Pharmacology, 8(11), 1553-1557.

Nath, A. (2018). Comprehensive study on negative effects of mobile phone/smart phone on human health. International Journal of Innovative Research in Computer and Communication Engineering, 6(1), $575-581$.

Oğuzkan, Ş. ve Oral, G. (1983). Okulöncesi Eğitimi, İstanbul: Milli Eğitim Bakanlığı Yayın Evi.

Ozdemir, B., Cakir, O., \& Hussain, I. (2018). Prevalence of Nomophobia among university students: A comparative study of Pakistani and Turkish undergraduate students. Eurasia Journal of Mathematics, Science and Technology Education, 14(4), 1519-1532.

Pavithra, M. B., Madhukumar, S., \& Mahadeva, M. (2015). A study on nomophobia-mobile phone dependence, among students of a medical college in Bangalore. National Journal of community medicine, 6(3), 340-344.

Peraman, R., \& Parasuraman, S. (2016). Mobile phone mania: arising global threat in public health. Journal Of Natural Science, Biology, And Medicine, 7(2), 198-200.

Prensky, M. (2001). Digital natives, digital immigrants. Retrieved 28.12.2019 from http://www.marcprensky.com/writing/Prensky\%20-

\%20Digital\%20Natives,\%20Digital\%20Immigrants\%20-\%20 Part1 .pdf

Reid, D.J. ve Reid, F., J., M. (2007). Text or Talk? Social anxiety, loneliness, and divergent preferences for cell phone use. CyberPsychology \& Behavior, 10(3), 424-35.

Samaha, M., \& Hawi, N. S. (2016). Relationships among smartphone addiction, stress, academic performance, and satisfaction with life. Computers in Human Behavior, 57, 321-325. 
Sırakaya, M. (2018). Ön lisans öğrencilerinin nomofobi düzeylerinin akıllı telefon kullanım durumlarına göre incelenmesi. Mersin Üniversitesi Eğitim Fakültesi Dergisi, 14(2), 714-727.

SecurEnvoy (2012). 66\% of The population suffer from nomophobia the fear of being without their phone. Retrieved 12.12.2019 from https://www.securenvoy.com/blog/2012/02/16/66-of-the-populationsuffer-from-nomophobia-the-fear-ofbeing-without-their-phone/.

Singh, P. R. K. (2018). Impact of insomniac problems and internet smart phones addictive behaviour of youth on their procrastination task persistence and academic performance. A Revised Synopsis Submitted to Dayalbagh Educational Institute (Deemed University) For the Partial Fulfillment of the Requirements For the Degree of Doctor Of Philosophy In Education.

Tabachnick, B. G., Fidell, L. S., \& Ullman, J. B. (2007). Using multivariate statistics (Vol. 5). Boston, MA: Pearson.Tams, S., Legoux, R., \& Leger, P. M. (2018). Smartphone withdrawal creates stress: A moderated mediation model of nomophobia, social threat, and phone withdrawal context. Computers in Human Behavior, 81, 1-9.

Tan, Ç., Pamuk, M. ve Dönder, A. (2013). Loneliness and mobile phone, Procedia - Social and Behavioral Sciences, 103(2013), 606-611.

Tanil, C. T., \& Yong, M. H. (2019). Mobile Phones: The Effect Of İts Presence On Learning And Memory. Biorxiv, 678094

Tavolacci, M. P., Meyrignac, G., Richard, L., Dechelotte, P., \& Ladner, J. (2015). Problematic use of mobile phone and nomophobia among French college students. The European Journal of Public Health, 25(3), 206-212.

Türen, U., Erdem, H. ve Kalkın, G. (2017). Mobil telefon yoksunluğu korkusu (nomofobi) yayılımı: türkiye'den üniversite öğrencileri ve kamu çalışanları örneklemi. Bilişsim Teknolojileri Dergisi, $10(1), 1-12$.

Uzun, M. ve Köse, A. (2017). Okul öncesi eğitimde değerler eğitiminin uygulanmasına yönelik öğretmen görüşleri. Bayburt Eğitim Fakültesi Dergisi, 12(23), 305-338.

Wei, R.i \& Lo, V. H. (2006). Staying connected while on the move: cell phone use and social connectedness. New Media \& Society, 8(1), 53-72.

Yıldırım, C., \& Correia, A. P. (2015). Understanding nomophobia: a modern age phobia among college students. In International Conference on Learning and Collaboration Technologies (pp. 724-735). Springer, Cham.

Yıldırım, S. ve Kişioğlu, A. N. (2018). Teknolojinin getirdiği yeni hastalıklar: nomofobi, netlessfobi, FoMO. Medical Journal of Suleyman Demirel University, 25(4).

Yildız Durak, H. (2018). What would you do without your smartphone? adolescents' social media usage, locus of control, and loneliness as a predictor of nomophobia. addicta: The Turkish Journal On Addictions, 5(2), 1-15.

Yildirim, C., Sumuer, E., Adnan, M., \& Yildirim, S. (2016). A growing fear: Prevalence of nomophobia among Turkish college students. Information Development, 32(5), 1322-1331.Young, K. (2015). The Digital Drug: Understanding and Treating Mobile Phone Addiction. In Encyclopedia of Mobile Phone Behavior (pp. 780-791). IGI Global. 


\section{EXTENTED ABSTRACT}

\section{Statement of Problem}

Today's technological tools affect human life in every way and become a need for almost every people. Even if mobile phones allow us to do many things quickly and efficiently, they will also bring negative factors (e.g. addictive behaviours) when they are overused (Nath, 2018). The most important of these problems is the discomfort associated with the use of the smartphone. In literature, there is a negative correlation between age and nomophobia. However, it is thought that the nomophobia levels of mobile phone usage behaviors and the nomophobia levels of the pre-school teachers are important. Studies in the literature about nomophobia reveal some variables related to nomophobia (Adnan \& Gezgin,2016; Büyükçolpan,2019; Durak, 2018a; Durak, 2018b; Gezgin et al.,2018; Gutiérrez-Puertas et al., 2019; Güler \& Veysikarani, 2019; Mallya et al.,2018; Surakaya, 2018). At the same time, there are no studies investigating the problems of the prevalence of nomophobia among teachers. In this study, the nomophobia levels of preschool teachers were emphasized. Accordingly, in this study, age and teaching profession year variables were controlled considering that the year of teaching profession increases with age, and it was aimed to investigate the difference between the smartphone use levels and nomophobia levels of pre-school teachers regardless of the effect of these controlled variables.

\section{Purpose of the Study}

Hence, the aim of this study was to investigate the nomophobia levels of pre-school teachers in terms of year of teaching profession, age and smartphone use skills.

\section{Method}

For this purpose, the study was designed in accordance with descriptive scanning method; in the different provinces of Turkey sampling consisted from 624 pre-school teachers. The nomophobia levels of the teachers were analysed to determine whether the nomophobia levels of the teachers make a significant difference compared to the smartphone usage levels regardless of the effect of the controlled variables i. g. age and teaching profession year. The results showed that pre-school teachers with the expert level of smartphone use are higher than at the novice and middle level of smartphone users based on ANCOVA by under control of professional teaching year and age variables.

\section{Findings and Discussion}

The results showed that pre-school teachers with the expert level of smartphone use are higher than at the novice and middle level of smartphone users based on ANCOVA by under control of professional teaching year and age variables. The findings indicate that the increase in the level of smartphone use may lead to an increase in the level of nomophobia risk. The high level of nomophobia of individuals using smartphones in an expert manner can be referred to the high level of 
nomophobia of individuals using intensive smartphones identified in the literature on nomophobia (Adnan \& Gezgin, 2016; Hoşgör et al., 2017). Because it is considered as a natural process that individuals who use smart phones intensively specialize in their use of smart phones and are open to updates of smart phones. However, since there is also the fear situation when nomophobia cannot reach friends and parents on the basis of nomophobia, in addition to the smartphone usage intensity and skill, the individual's personal characteristics, anxiety, mood-change and especially loneliness (Tan et al., 2013; Gezgin et al., 2018; Jin \& Park, 2012; Reid \& Reid, 2007; Wei \& Lo, 2006; Ozdemir et al.,2018; Jiang \& Shypenka, 2018). Regardless of age and year of teaching profession, it can be said that teachers who self-update herself/himself and are open to developments with technology competence and predisposition have a risk of nomophobia. This can be explained by Griffiths' (2003) suggestion that everything that gives pleasure is addictive. Thus, it is thought that the risk of nomophobia may be reduced by preventing the unconscious and uncontrolled increase at the level of the use of smartphone by gaining experience by interacting with the applications installed on the smartphone in his spare time.

\section{Conclusions and Recommendations}

As a result of this study, we can conclude that the increase of the use of smartphone level increases the risk of nomophobia in all ages and career stages. Although generation $\mathrm{X}$ is considered more traditional, it is seen that preschool teachers who are technically qualified and open to technological developments may be affected by nomophobia due to the use of smart phones as experts. Therefore, based on the findings obtained in the study, the idea that smart phones should be used according to the needs is increasing day by day and it is important to go beyond using it as a leisure activity. In further studies, different measurement methods can be used for mobile usage level. In this respect, it can be said that the studies to increase the digital literacy skills of individuals can have effective results in terms of combating nomophobia. 